Jurnal Pemikiran \& Penelitian Psikologi

\title{
PSIKOLOGIA
}

p-ISSN: $185-0327$

e-ISSN: 2549-2136

www.jurnal.usu.ac.id/psikologia

\section{PENGARUH IKLIM ORGANISASI DAN KEADILAN ORGANISASI TERHADAP ORGANIZATIONAL CITIZENSHIP BEHAVIOR}

\section{THE EFFECT OF ORGANIZATIONAL CLIMATE AND ORGANIZATIONAL JUSTICE ON ORGANIZATIONAL CITIZENSHIP BEHAVIOR}

Siti Jamilah, Emmy Mariatin, Ferry Novliadi

Psikologia: Jurnal Pemikiran \& Penelitian Psikologi

Tahun 2017, Vol. 12, No. 3, hal.122-133

Artikel ini dapat diakses dan diunduh pada:

www.jurnal.usu.ac.id/psikologia

Dipublikasikan oleh:

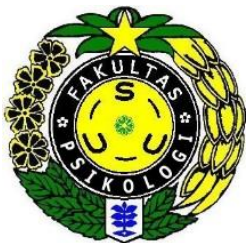

Fakultas Psikologi

Universitas Sumatera Utara

Jl. Dr. Mansyur No. 7 Medan. Telp/fax: 061-8220122

Email: psikologia@usu.ac.id 


\title{
PENGARUH IKLIM ORGANISASI DAN KEADILAN ORGANISASI TERHADAP ORGANIZATIONAL CITIZENSHIP BEHAVIOR
}

\author{
Siti Jamilah, Emmy Mariatin, Ferry Novliadi \\ Universitas Sumatera Utara
}

\begin{abstract}
ABSTRAK
Penelitian ini bertujuan untuk melihat pengaruh iklim organisasi dan keadilan organisasi terhadap organizational citizenship behavior. Metode penelitian menggunakan metode kuantitatif dengan alat ukur skala masing-masing variabel. Teknik analisis yang digunakan dalam penelitian ini adalah teknik analisis regresi linier berganda. Seluruh pegawai PT. X yang berjumlah 307 orang dijadikan subjek penelitian dengan data yang terkumpul sebanyak 246. Hasilnya ditemukan bahwa iklim organisasi berpengaruh positif dan signifikan terhadap organizational citizenship behavior yaitu sebesar $42.1 \%$. Keadilan organisasi juga berpengaruh positif dan signifikan terhadap organizational citizenship behavior, yaitu sebesar 30.3\%. Iklim organisasi dan keadilan organisasi secara bersama-sama berpengaruh terhadap organizational citizenship behavior dengan yaitu sebesar $42.9 \%$. Hasil analisis kategorisasi berdasarkan rerata empirik menunjukkan bahwa rata-rata pegawai PT. X memiliki tingkat organizational citizenship behavior yang tinggi, persepsi iklim organisasi yang positif, dan hampir keseluruhan memiliki persepsi keadilan organisasi yang tinggi.
\end{abstract}

Kata-kata kunci: Iklim Organisasi, Keadilan Organisasi, Organizational Citizenship Behavior

\section{THE EFFECT OF ORGANIZATIONAL CLIMATE AND ORGANIZATIONAL JUSTICE ON ORGANIZATIONAL CITIZENSHIP BEHAVIOR}

\begin{abstract}
S
This study aims to see the influence of organizational climate and organizational justice to organizational citizenship behavior. The research method using quantitative method with scale measuring tool of each variable. The analysis technique used in this research is multiple linear regression analysis technique. All employees of PT. X which amounted to 307 people made the subject of research with data collected as much as 246 . The result found that the organizational climate has a positive influence and significant impact on organizational citizenship behavior, the contribution is $42.1 \%$. Organizational justice also has a positive and significant impact on organizational citizenship behavior, the contribution is $30.3 \%$. The organizational climate and organizational justice together affect the organizational citizenship behavior with effective contribution of $42.9 \%$. The result of categorization analysis based on empirical average shows that the average employee of PT. X has high organizational citizenship behavior levels, positive organizational climate perceptions, and almost all have high organizational fairness perceptions.
\end{abstract}

Keywords: Organizational Climate, Organizational Justice, Organizational Citizenship Behavior

*Korespondensi mengenai penelitian ini dapat dilayangkan kepada: Psikologia@usu.ac.id
Rekomendasi mensitasi:

Jamilah,S. Mariatin,E. Novliadi,F. (2017). Pengaruh Keadilan Organisasi dan Keadilan Organisasi terhadap Organizational Citizenship Behavior. Psikologia :Jurnal Pemikiran dan Penelitian Psikologi, 12(3), 122133 


\section{PENDAHULUAN}

Dalam era globalisasi saat ini, setiap perusahaan dituntut untuk semakin menunjukkan kinerja yang handal agar dapat mempertahankan eksistensinya. Kesuksesan perusahaan dalam hal ini berkaitan dengan sumber daya yang tersedia, terutama sumber daya manusia sebagai intangible asset perusahaan (Aylitalia, 2014). Efektifitas suatu perusahaan sangat ditentukan oleh perilaku para individu di dalamnya. Perilaku tersebut tidak hanya mencakup perilaku in-role saja, tetapi diharapkan dapat lebih memunculkan perilaku extrarole dari individu tersebut. Perilaku extrarole sering disebut pula sebagai organizational citizenship behavior. Organizational citizenship behavior merupakan perilaku pegawai yang bekerja tidak hanya pada apa yang menjadi tugasnya (in-role), tetapi melebihi tugas formalnya (Sahertian, 2010).

Menurut Soegandhi, Sutanto \& Setiawan (2013), salah satu faktor yang mempengaruhi organizational citizenship behavior yaitu iklim organisasi. Berdasarkan penelitian terdahulu, ditemukan bahwa iklim organisasi berpengaruh secara signifikan terhadap organizational citizenship behavior. Iklim organisasi akan menentukan apakah seseorang dapat melaksanakan tugas dan tanggung jawab sesuai prosedur atau tidak (Saleh 2015). Iklim organisasi itu sendiri adalah hasil dari tingkah laku anggota di dalam organisasi sebagai kualitas lingkungan internal organisasi yang dipertahankan sehingga membedakan organisasi tersebut dengan organisasi lain (Karismawan, 2005).
Selain iklim organisasi, terdapat faktor lain yang dapat berpegaruh terhadap organizational citizenship behavior. Menurut Jahangir, Akbar \& Haq (2004), keadilan organisasi sebagai salah satu faktor yang berpengaruh terhadap organizational citizenship behavior. Dari penelitian sebelumnya terkait dengan pengaruh keadilan organisasi terhadap organizational citizenship behavior, ditemukan bahwa keadilan organisasi berpengaruh terhadap organizational citizenship behavior (Pasca, 2015). Keadilan organisasi diartikan sebagai suatu tingkat di mana seorang individu merasa diperlakukan sama di dalam organisasi tempat dia bekerja (Gibson et al, 2012). Menurut Ivancevich (2008), terdapat keadilan distributif yang berkaitan dengan alokasi imbalan yang berlaku di perusahaan, keadilan prosedural terkait pelaksanaan kerja secara merata bagi seluruh pegawai. Keadilan interaksional diartikan sebagai tingkat kesamarataan persebaran informasi dan interaksi antar rekan kerja maupun antara atasan dan bawahan di perusahaan (Greenberg \& Baron, 2003).

Fenomena organizational citizenship behavior pegawai sangat tergambar di PT. $\mathrm{X}$. Berdasarkan fenomena yang terlihat dan dari data yang didapat, ditemukan bahwa para pegawai menunjukkan organizational citizenship behavior yang tinggi. Berdasarkan hasil survei pada tahun 2015, dari 795 pegawai terdapat $93 \%$ orang yang menunjukkan organizational citizenship behavior yang tinggi sedangkan pegawai yang menunjukkan organizational citizenship behavior yang rendah hanya $7 \%$ (PIC Kinerja, 2015). Bahkan pada tahun 2016, dari 943 pegawai terdapat sebanyak $96 \%$ 
yang menunjukkan organizational citizenship behavior yang tinggi sedangkan pegawai yang menunjukkan organizational citizenship behavior yang rendah hanya sebanyak 4\%. Hal ini dapat dikatakan bahwa jumlah pegawai yang menunjukkan organizational citizenship behavior yang tinggi meningkat sebesar 3\% (PIC Kinerja, 2016).

Berdasarkan hasil observasi, para pegawai saling tolong menolong dalam melaksanakan pekerjaan dan bahkan saling membantu dalam menyelesaikan permasalahan yang terjadi termasuk permasalahan di luar masalah pekerjaan seperti masalah keluarga. Begitu pula pimpinan atau pihak manajemen yang peduli terhadap para pegawai yang mengalami permasalahan dengan membantu menyelesaikan masalah yang menjadi kendala bagi pegawai sehingga tidak menganggu kinerjanya terhadap perusahaan.

Di sisi lain, pegawai menunjukkan organizational citizenship behavior karena keadilan organisasi yang dimiliki oleh PT. X. Berdasarkan hasil wawancara, para pegawai merasa bahwa perusahaan telah memperlakukan pegawai dengan adil, telah memberikan berbagai imbalan dari hasil kerja pegawai sehingga pegawai lebih terdorong untuk memberikan kinerja yang lebih baik lagi hingga mencapai target kerja. Di PT. X, setiap pegawai diperlakukan sama atas timbal balik dari kinerjanya. Pegawai dengan kinerja bagus diapresiai dengan penghargaan dan jika berpotensi akan dipromosikan, sedangkan pegawai yang melakukan kesalahan akan diberi peringatan atau hukuman.

Fenomena di atas menunjukkan bahwa organizational citizenship behavior dipengaruhi oleh iklim organisasi dan

*Korespondensi mengenai penelitian ini dapat dilayangkan kepada: Psikologia@usu.ac.id keadilan organisasi. Oleh karena itu, ada kemungkinan bahwa iklim organisasi dan keadilan organisasi yang dirasakan oleh pegawai di PT. X secara bersama-sama memiliki pengaruh terhadap organizational citizenship behavior pegawai. Dengan demikian, penelitian ini bertujuan untuk melihat mengetahui pengaruh iklim organisasi dan keadilan organisasi terhadap organizational citizenship behavior.

\section{KERANGKA TEORITIS}

\section{Organizational Citizenship Behavior}

Organizational citizenship behavior merupakan perilaku yang dilakukan dengan inisiatif sendiri, tidak secara langsung diatur dalam rincian pekerjaan yang formal, yang akan meningkatkan efektivitas perusahaan (Podsakoff, \& MacKinzie, 2006). Menurut Luthans (2006), organizational citizenship behavior tidak diatur dalam sistem formal di dalam perusahaan dan tidak memiliki balasan/penghargaan pula, karyawan yang melakukan organizational citizenship behavior bertindak secara sukarela.

Organizational citizenship behavior terdiri dari lima dimensi (Podsakoff, \& MacKinzie, 2006), yaitu altruism perilaku membantu rekan kerja, courtesy perilaku menjaga diri agar tidak menimbulkan masalah di tempat kerja, conscientiousness perilaku yang menunjukkan dedikasi yang tinggi terhadap pekerjaan, sportsmanship perilaku yang menunjukkan kesediaan dalam menerima berbagai keadaan di dalam perusahaa, dan civic virtue perilaku peduli terhadap perusahaan yang ditunjukkan dengan berpartisipasi aktif dalam berbagai kegiatan yang diselenggarakan oleh perusahaan.

\section{Rekomendasi mensitasi:}

Jamilah,S. Mariatin,E. Novliadi,F. (2017). Pengaruh Keadilan Organisasi dan Keadilan Organisasi terhadap Organizational Citizenship Behavior. Psikologia :Jurnal Pemikiran dan Penelitian Psikologi, 12(3), 122- 


\section{Iklim Organisasi}

Iklim organisasi merupakan kualitas lingkungan internal organisasi yang dialami oleh anggota organisasi dan mempengaruhi perilaku anggota organisasi tersebut (Stringer; Wirawan, 2007). Selanjutnya Steers, Porter, \& Bigley (2003) mengungkapkan, iklim organisasi sebagai kepribadian suatu organisasi sebagaimana yang dilihat atau dirasakan oleh para anggota organisasi tersebut. Iklim organisasi merupakan hasil suatu tindakan yang telah ditempuh baik secara sadar ataupun tidak oleh suatu organisasi yang berpengaruh terhadap tingkah laku anggotanya.

Iklim organisasi dibentuk oleh enam dimensi (Stringer; Wirawan, 2007), yaitu struktur yang mengacu pada peran dan tanggung jawab anggota organisasi yang jelas, standar yang menandai adanya acuan bagi anggota perusahaan dalam menunjukkan kinerjanya, tanggung jawab yang merefleksikan kemandirian pegawai dalam menyelesaikan pekerjaan ataupun menentukan keputusannya secara mandiri, pengakuan yang menggambarkan timbal balik yang diterima pegawai dari hasil kerjanya, dukungan yang meliputi hubungan pegawai dengan rekan kerjanya, dan komitmen yang merefleksikan derajat pemahaman pegawai terhadap tujuan yang ingin dicapai oleh perusahaan yang ditunjukkan oleh kebanggaan pegawai terhadap perusahaan.

\section{Keadilan Organisasi}

Keadilan organisasi adalah persepsi karyawan mengenai seberapa adil mereka diperlakukan dalam bekerja dan berinteraksi di tempat kerja (Ivancevich, 2008). Greenberg \& Baron (2003) menjelaskan bahwa keadilan organisasi adalah persepsi secara keseluruhan anggota organisasi terhadap keadilan yang berlaku di organisasi terkait imbalan yang diterima, keputusan dan prosedur kerja yang berlaku, dan persamaan perlakuan bagi setiap anggota perusahaan di dalam organisasi.

Keadilan organisasi dikonseptualisasikan sebagai kombinasi dari tiga dimensi (Greenberg \& Baron, 2003), yaitu keadilan distributif terkait keadilan yang didapatkan anggota organisasi dari organisasi telah sesuai dengan apa yang mereka lakukan untuk organisasi, keadilan prosedural mengenai proses yang digunakan untuk menentukan distribusi hasil kerja dan penghargaan-penghargaan bagi anggota organisasi, dan keadilan interaksional yang mengacu pada transparansi berbagai informasi di dalam organisasi dan perlakuan yang bermartabat bagi setiap anggota organisasi.

\section{HIPOTESA PENELITIAN}

Hipotesis yang akan diuji dalam penelitian ini antara lain:

1. Iklim organisasi berpengaruh positif dan signifikan terhadap organizational citizenship behavior.

2. Keadilan organisasi berpengaruh positif dan signifikan terhadap organizational citizenship behavior.

Iklim organisasi dan keadilan organisasi secara bersama-sama berpengaruh positif dan signifikan terhadap organizational citizenship behavior.

\section{METODE}

Metode pengumpulan data yang digunakan pada penelitian ini adalah metode kuesioner. Penyusunan kuesioner dalam penelitian ini menggunakan skala likert yang digunakan untuk mengukur 
sikap, pendapat, dan persepsi seseorang atau sekelompok orang mengenai suatu objek (Sugiyono, 2011).

\section{HASIL}

\section{Uji Normalitas}

Uji normalitas sebaran dilakukan dengan menggunakan one sample kolmogorov smirnov test yang dilakukan pada variabel iklim organisasi, keadilan organisasi, dan organizational citizenship behavior. Analisis data kolmogorov smirnov menunjukkan bahwa data penelitian terdistribusi normal, pada variabel iklim organisasi menunjukkan sebaran normal dengan nilai signifikansi $\mathrm{P}=0,113(>0,05)$. Pada variabel keadilan organisasi menunjukkan sebaran normal dengan nilai signifikansi $\mathrm{P}=0.072$ (> 0,05). Pada variabel organizational citizenship behavior juga menunjukkan sebaran normal dengan nilai $\mathrm{P}=0,072$ (> $0,05)$.

\section{Uji Linearitas}

Berdasarkan uji asumsi linearitas antara variabel iklim organisasi dan organizational citizenship behavior ditemukan nilai signifikansi linearity 0.000 ( $\mathrm{p}<0.05)$. Uji asumsi linearitas antara variabel keadilan organisasi dan organizational citizenship behavior ditemukan nilai signifikansi liniearity 0.000 ( $\mathrm{p}<0.05$ ). Dengan demikian dapat dikatakan bahwa antara variabel bebas dengan variabel tergantung hubungannnya linier.

\section{Uji Multikolinearitas}

Berdasarkan

uji

asumsi

multikolinearitas, diketahui bahwa nilai (Variance Inflation Factor) VIF masingmasing prediktor (iklim organisasi dan

*Korespondensi mengenai penelitian ini dapat dilayangkan kepada: Psikologia@usu.ac.id keadilan organisasi) adalah 2.238 dengan nilai tolerance 0.447 . Karena nilai VIF < 5 dan nilai tolerance $>0.1$, dapat disimpulkan bahwa tidak terjadi multikolinearitas antar variabel bebas. Dengan demikian, diasumsikan bahwa tidak terjadi hubungan linear antar variabel bebas dan uji asumsi multikolinearitas terpenuhi.

\section{Uji Heterokedastisitas}

Berdasarkan dari grafik di bawah ini dapat dilihat bahwa sebaran titik dalam grafik menyebar secara acak (no systematic pattern) di sekitar 0, dan titiktitik menyebar di atas dan di bawah angka 0 pada sumbu Y. Maka disimpulkan bahwa tidak terjadi gejala heterokedesitas dalam model regresi dan uji asumsi heterokedastisitas terpenuhi.

\section{Grafik Uji Asumsi \\ Keterokedastisitas}

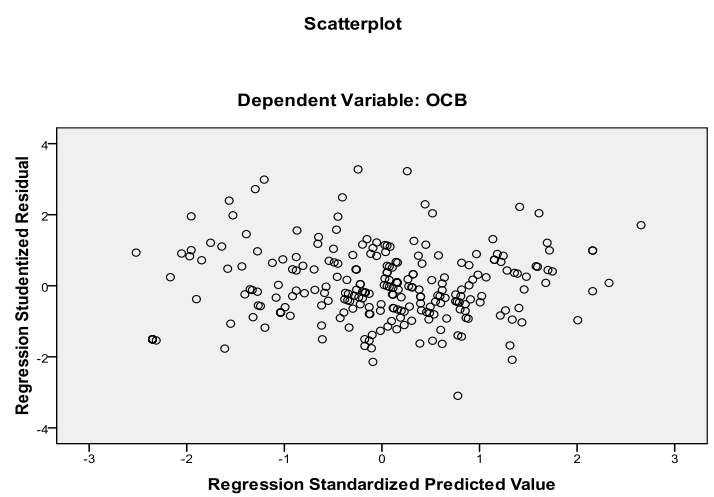

\section{Uji Autokorelasi}

Berdasarkan uji Durbin-Watson, nilai statistik dari uji Durbin-Watson berada di antara 1 dan 3 yaitu 1.831, maka disimpulkan tidak terjadi autokorelasi.

\section{Hasil Uji Hipotesa Penelitian}

Teknik statisik yang digunakan untuk menguji hipotesis dalam penelitian ini adalah teknik analisis regresi linier berganda. Analisis regresi linier berganda

Rekomendasi mensitasi:

Jamilah,S. Mariatin,E. Novliadi,F. (2017). Pengaruh Keadilan Organisasi dan Keadilan Organisasi terhadap Organizational Citizenship Behavior. Psikologia :Jurnal Pemikiran dan Penelitian Psikologi, 12(3), 122- 
digunakan karena dapat memprediksi atau mengestimasi nilai dari variabel tak bebas berdasarkan informasi dari variabel bebas

Berdasarkan hasil uji regresi di atas, dihasilkan nilai signifikansi $0.00(<0.05)$ pada regresi iklim organisasi dan organizational citizenship behavior. Dengan demikian, maka dapat disimpulkan bahwa iklim organisasi
(Gio \& Rosmaini, 2015). Adapun hasil analisa hipotesa penelitian ini adalah:

\section{Tabel Hasil Uji Regresi}

keadilan organisasi secara positif terhadap organizational citizenship behavior adalah $30.3 \%$ sedangkan sisanya sebesar $69.7 \%$ dijelaskan oleh sebab-sebab lain di luar model penelitian. Dengan demikian, dari penejelasan di atas dapat disimpulkan

\begin{tabular}{ccccccc}
\hline $\begin{array}{c}\text { Variabel } \\
\text { Dependent }\end{array}$ & Variabel Independent & Sig. & Beta & R & R Square & $\begin{array}{c}\text { Ajusted R } \\
\text { Square }\end{array}$ \\
\hline Organizational & Iklim Organisasi & 0.000 & 0.473 & 0.651 & 0.423 & 0.421 \\
$\begin{array}{c}\text { Citizenship } \\
\text { Behavior }\end{array}$ & Keadilan Organisasi & 0.000 & 0.630 & 0.553 & 0.306 & 0.303 \\
& $\begin{array}{l}\text { Iklim Organisasi dan } \\
\text { Keadilan Organisasi }\end{array}$ & 0.000 & $0.389(\mathrm{IO})$ & 0.659 & 0.434 & 0.429 \\
\hline
\end{tabular}

berpengaruh secara signifikan terhadap organizational citizenship behavior. Berdasarkan uji determinasi $\mathrm{R}$, dapat dilihat koefisien determinan (adjusted $\mathrm{R}$ square) sebesar 0.421 dengan nilai (+), artinya kontribusi variabel iklim organisasi secara positif terhadap organizational citizenship behavior adalah $42.1 \%$ sedangkan sisanya sebesar $57.9 \%$ dijelaskan oleh sebab-sebab lain di luar model penelitian.

Dengan demikian, dari penejelasan di atas dapat disimpulkan bahwa hipotesis 1 diterima, iklim organisasi berpengaruh positif dan signifikan terhadap organizational citizenship behavior.

Selanjutnya, dapat dilihat nilai signifikansi 0.00 (< 0.05$)$ pada regresi keadilan organisasi dan organizational citizenship behavior. Dengan demikian, maka dapat disimpulkan bahwa keadilan organisasi berpengaruh secara signifikan terhadap organizational citizenship behavior. Berdasarkan uji determinasi R, dapat dilihat koefisien determinan (adjusted $\mathrm{R}$ square) sebesar 0.303 dengan nilai (+), artinya kontribusi variabel bahwa hipotesis 2 diterima, keadilan organisasi berpengaruh positif dan signifikan terhadap organizational citizenship behavior.

Terakhir, dari uji regresi antara iklim organisasi dan keadilan organisasi terhadap organizational citizenship behavior didapatkan nilai signifikansi 0.00 $(<0.05)$. Dengan demikian, maka dapat disimpulkan bahwa iklim organisasi dan keadilan organisasi berpengaruh secara signifikan terhadap organizational citizenship behavior. Berdasarkan uji determinasi $\mathrm{R}$, dapat dilihat koefisien determinan (adjusted $\mathrm{R}$ square) sebesar 0.429 dengan nilai (+), artinya kontribusi variabel iklim organisasi dan keadilan organisasi secara bersama-sama terhadap organizational citizenship behavior adalah 42.9\% sedangkan sisanya sebesar $57.1 \%$ dijelaskan oleh sebab-sebab lain di luar model penelitian. Dengan demikian, dari penejelasan di atas dapat disimpulkan bahwa hipotesis 3 diterima, yaitu iklim organisasi dan keadilan organisasi secara bersama-sama berpengaruh positif dan 
signifikan terhadap organizational citizenship behavior.

\section{DISKUSI}

Dari hasil penelitian ini, ditemukan bahwa secara keseluruhan pegawai PT. X menunjukkan perilaku kesukarelaan (extra-role) atau yang biasa disebut sebagai organizational citizenship behavior. Para pegawai bersedia melakukan hal di luar tugas formalnya secara sukarela untuk kepentingan perusahaan. Munculnya organizational citizenship behavior pegawai didukung oleh kualitas lingkungan di dalam perusahaan, dari struktur, standar, dan tanggung jawab yang telah diatur secara jelas di dalam perusahaan, adanya timbal balik dari hasil kerja pegawai, interaksi yang harmonis antar pegawai dan saling bantu dalam menjalankan pekerjaan hingga memunculkan loyalitas pegawai terhadap perusahaan. Di PT. X, terdapat program yang Employee Day Forum (EDF) dengan tujuan untuk memobilisasi seluruh sumber daya dari organisasi untuk pencapaian tujuan perusahaan dengan menetapkan prioritas dan tindakan untuk perusahaan. Program ini membentuk iklim organisasi yang positif dimana seluruh pegawai merasa dilibatkan di dalam perusahaan dan terbangun hubungan keakraban antar pegawai (Jamilah, 2017).

Iklim organisasi merupakan hal penting yang terbentuk di dalam perusahaan berdasarkan persepsi anggota perusahaan tentang apa yang ada di dalam perusahaan dan menjadi dasar bagi anggota perusahaan tersebut dalam bertindak di dalam perusahaan. Rata-rata pegawai PT. X mempersepsikan kualitas iklim organisasi secara positif yaitu

*Korespondensi mengenai penelitian ini dapat dilayangkan kepada: Psikologia@usu.ac.id sebesar $78.05 \%$ atau sebanyak 192 pegawai mempersepsikan kualitas iklim organisasi secara positif. Menurut Stringer \& Litwin (2008), iklim organisasi mendorong pegawai untuk bekerja lebih baik dan iklim organisasi yang positif mendasari pegawai dalam menunjukkan perilaku kerja kewargaan atau organizational citizenship behavior. Sehingga ditemukan pula, rata-rata pegawai PT. X memiliki tingkat organizational citizenship behavior yang tergolong tinggi dengan jumlah 200 orang pegawai dari 246 responden atau $81.3 \%$.

Berdasarkan hasil analisis data yang telah dilakukan, dapat dijelaskan bahwa iklim organisasi berpengaruh positif terhadap organizational citizenship behavior pegawai. Hal ini menunjukkan bahwa semakin positif kualitas iklim organisasi bagi pegawai, maka semakin tinggi pula organizational citizenship behavior pegawai. Hasil penelitian ini mendukung hasil penelitian yang telah dilakukan sebelumnya oleh Widyana (2014) dan Saleh (2015) yang menemukan bahwa iklim organisasi berpengaruh positif terhadap organizational citizenship behavior, semakin positif iklim organisasi bagi anggota organisasi akan semakin meningkatkan organizational citizenship behavior anggota organisasi.

Hasil penelitian ini juga menunjukkan adanya pengaruh positif keadilan organisasi terhadap organizational citizenship behavior. Hal ini menjelaskan bahwa semakin tinggi tingkat keadilan organisasi, maka semakin tinggi pula organizational citizenship behavior pegawai. Hal ini sesuai dengan hasil penelitian yang telah dilakukan oleh Zeinabadi \& Salehi (2011) dan Pasca (2015), yang menemukan bahwa keadilan

\section{Rekomendasi mensitasi:}

Jamilah,S. Mariatin,E. Novliadi,F. (2017). Pengaruh Keadilan Organisasi dan Keadilan Organisasi terhadap Organizational Citizenship Behavior. Psikologia :Jurnal Pemikiran dan Penelitian Psikologi, 12(3), 122- 
organisasi memiliki pengaruh terhadap organizational citizenship behavior.

Dari hasil penelitian ini, ditemukan hampir seluruh pegawai PT. X memiliki persepsi keadilan organisasi yang tinggi hingga mencapai $99.919 \%$. Selain itu didapatkan juga besarnya kontribusi keadilan organisasi terhadap organizational citizenship behavior sebesar $30.6 \%$ dan bernilai positif, sehingga dapat dikatakan bahwa terdapat pengaruh positif antara keadilan organisasi dan organizational citizenship behavior. Artinya, meningkatnya keadilan organisasi yang dipersepsikan pegawai maka meningkat pula organizational citizenship behavior pegawai.

Keadilan organisasi di dalam perusahaan yang dirasakan pegawai didapatkan dari imbalan ataupun penghargaan yang sesuai dengan kinerja yang telah mereka berikan. Pegawai juga merasakan kejelasan informasi terkait berbagai keputusan dan aturan yang diterapkan, walaupun para pegawai tidak mendapat informasi terkait potensi dan kompetensinya berdasarkan hasil assessment dalam talent management yang dilaksanakan pegawai karena kebijakan perusahaan yang tidak membenarkan para pegawai mengetahui hasil assessment yang dilaksanakan. Di sisi lain, interaksi yang dirasakan pegawai di dalam perusahaan membuat pegawai merasa dihargai dan antar pegawai saling menghormati tanpa ada perbedaan perlakukan sehingga pegawai merasakan keadilan di dalam perusahaan.

Menurut Luthans (2006), keadilan organisasi menjadi hal yang penting terhadap organizational citizenship behavior, pegawai harus merasa bahwa mereka diperlakukan dengan adil sehingga mendorong mereka untuk melakukan organizational citizenship behavior. Para pegawai yang merasa diperlakukan dengan adil akan mendorong munculnya organizational citizenship behavior. Hal ini juga yang terjadi dengan pegawai PT. $\mathrm{X}$ yang menunjukan tingkat organizational citizenship behavior, dimana organizational citizenship behavior pegawai muncul karena pegawai telah mendapatkan perlakukan yang adil di dalam perusahaan dan persepsi pegawai terhadap keadilan organisasi tinggi.

Hasil penelitian ini juga menunjukkan bahwa iklim organisasi dan keadilan organisasi secara bersama-sama menjadi prediktor bagi organizational citizenship behavior pegawai dengan kontribusi sebesar $42.9 \%$. Artinya, iklim organisasi dan keadilan organisasi memberikan kontribusi sebesar $42.9 \%$, sedangkan sisanya sebesar $57.1 \%$ dipengaruhi oleh faktor lain. Dari hasil tersebut dapat dikatakan bahwa jika kualitas iklim organisasi dan tingkat keadilan organisasi semakin tinggi, maka akan meningkatkan organizational citizenship behavior pegawai.

Para pegawai PT. X merasakan iklim organisasi yang positif, dimana kerjasama antar pegawai sangat terasa dengan sikap saling tolong menolong dan terasa hubungan kekeluargaan dimana antar pegawai saling membantu dalam menyelesaikan permasalahan yang terjadi termasuk masalah pribadi serta pimpinan atau pihak manajemen yang menunjukkan kepedulian. Para pegawai juga merasakan keadilan organisasi yang tinggi di dalam perusahaan, pegawai merasa bahwa perusahaan telah memperlakukan pegawai dengan adil melalui imbalan dari hasil kerja pegawai, transparansi pengambilan keputusan dan berbagai informasi yang disebarkan, dan hubungan interaksional 
bagi setiap pegawai yang merata. Iklim organisasi yang positif dan keadilan organisasi yang tinggi tersebut yang mendorong pegawai menunjukkan organizational citizenship behavior.

\section{KESIMPULAN}

1. Iklim organisasi berpengaruh positif dan signifikan terhadap organizational citizenship behavior pegawai PT. X. Semakin positif kualitas iklim organisasi akan diikuti oleh organizational citizenship behavior yang semakin tinggi pula;

2. Keadilan organisasi berpengaruh positif dan signifikan terhadap organizational citizenship behavior pegawai PT. X. Semakin tinggi keadilan organisasi yang dipersepsikan pegawai maka semakin tinggi organizational citizenship behavior pegawai;

3. Iklim organisasi dan keadilan organisasi secara bersama-sama berpengaruh terhadap organizational citizenship behavior pegawai PT. X. Iklim organisasi dan keadilan organisasi berperan dalam peningkatan organizational citizenship behavior pegawai;

4. Besarnya kontribusi iklim organisasi dan keadilan organisasi terhadap organizational citizenship behavior adalah sebesar $42.9 \%$;

5. Rata-rata pegawai PT. X memiliki tingkat organizational citizenship behavior yang tinggi, persepsi iklim organisasi yang positif, dan hampir keseluruhan memiliki persepsi terhadap keadilan organisasi yang tinggi.
*Korespondensi mengenai penelitian ini dapat dilayangkan kepada: Psikologia@usu.ac.id

\section{SARAN}

1. Saran Metodologis

a. Berdasarkan berbagai literatur, terdapat banyak faktor yang dapat mempengaruhi organizational citizenship behavior. Oleh karena itu, disarankan untuk penelitian lanjutan agar menguji pengaruh dari variabel lainnya yang mungkin memiliki kontribusi terhadap organizational citizenship behavior;

b. Berdasarkan metode enter yang digunakan untuk melakukan analisis regresi berganda dalam penelitian ini, didapatkan hasil berupa kontribusi variabel bebas secara bersama-sama terhadap variabel tergantung tanpa diketahui kontribusi dari masing-masing variabel bebas tersebut. Oleh karena itu, disarankan untuk penelitian lanjutan untuk dapat menggunakan metode stepwise yang dapat langsung menunjukkan hasil (kontribusi) dari masingmasing variabel bebas terhadap variabel tergantung sehingga hasil yang didapatkan lebih jelas dan lebih rinci.

\section{Saran Praktis}

a. Perusahaan hendaknya mempertahankan iklim organisasi yang positif melalui program Employee Day Forum (EDF). Dimana, dilakukan pengembangan agenda di dalamnya untuk lebih meningkatkan kualitas iklim organisasi menjadi lebih positif seperti pembahasan code of conduct yang dilaksanaakn pegawai atau pengumuman

\section{Rekomendasi mensitasi:}

Jamilah,S. Mariatin,E. Novliadi,F. (2017). Pengaruh Keadilan Organisasi dan Keadilan Organisasi terhadap 
penghargaan bagi pegawai dengan kinerja tinggi ataupun hal-hal lainnya;

b. Perusahaan hendaknya mempertahankan tingkat keadilan organisasi yang tinggi di perusahaan, akan tetapi perusahaan perlu memperhatikan keadilan informasional terkait hasil assessment yang dilaksanakan pegawai. Berdasarkan hasil wawancara, pegawai berharap mengetahui hasil assessment karena berguna untuk pegawai dalam memahami pribadinya terkait potensi dan kompetensi yang dimilikinya sehingga pegawai dapat pula melakukan introspeksi diri apabila masih memiliki kekurangan dalam memberikan kontribusi terhadap perusahaan.

\section{REFERENSI}

Agung, A. W. \& Lussy, M. (2012). Pengaruh Kepuasan Kerja dan Iklim Organisasi Terhadap Organizational Citizenship Behavior (OCB) Karyawan Pada PT Trubus Swadaya. Jurnal Riset Manajemen Sains Indonesia (JRMSI), 3 (1).

Alugoro. (2002). Analisis Pengaruh Iklim Kerja Terhadap Kepuasan Kerja Pegawai di Sekretaritas Daerah Kota Semarang. (Tesis). Universitas Diponegoro, Semarang.

Arikunto, S. (2002). Prosedur Penelitian: Suatu Pendekatan Praktek. Jakarta: Rineka Cipta.

Aylitalia. (2014). Gaya Kepemimpinan Task Oriented, Manajemen
Reward Non Finansial dan Motivasi Kerja. Persona, Jurnal Psikologi Indonesia, 3 (2). Surabaya.

Azwar, S. (2005). Penyusunan Skala Psikologi. Yogyakarta: Pustaka Pelajar.

Azwar, S. (2012). Metode penelitian. Yogyakarta: Pustaka Pelajar.

Bambang, K. (2003). Undang-Undang Republik Indonesia Tentang Ketenagakerjaan. Lembaga Negara Republik Indonesia. Jakarta.

Cahayu, A. S. \& Adnyani, A. D. (2015). Pengaruh Keadilan Organisasi Terhadap Kepuasan Kerja dan Organizational Citizenship Behavior Pada Karyawan Toko Nyoman. E-Jurnal Manajemen Unud, 4 (11).

Colquitt, J. A., Jeffrey, A. L., \& Michael, J. W. (2010). Organizational Behavior: Essential for Improving Performance and Commitment. New York: McGraw-Hill.

Field, A. (2009). Discovering statistics using SPSS $3^{\text {rd }}$ Ed. London: SAGE Publications Ltd.

Gibson, J. L., Donnelly, J. H., Ivancevich, J. M., \& Konopaske, R. (2012). Organizations: Behavior, structure, processes. Singapore: McGraw-Hill.

Gio, P. U. \& Rosmaini, E. (2015). Belajar Olah Data dengan SPSS, MINITAB, $R, \quad$ MICROSOFT EXCEL, EVIEWS, LISREL, AMOS, dan SMARTPLS. Medan: USU Press. 
Greenberg, J. \& Baron, R.A. (2003). Behaviour in Organizations $8^{\text {th }}$ Edition. New Jersey: Prentice Hall.

Greenberg, J. \& Baron, R.A. (2008). Behaviour in Organizations $9^{\text {th }}$ Edition. New Jersey: Pearson Education International.

Isaac, S \& Michael, W. B. (1997). Handbook in Research and Evaluation $3^{\text {rd }}$ Ed. Educational and Industrial Testing Services: San Diego California.

Ivancevich, J. M. (2008). Perilaku dan Manajemen Organisasi. Jakarta: Erlangga.

Jafari, P. \& Bidarian, S. (2012). The Relationship between Organizational Justice and Organizational Citizenship Behavior. Procedia-Social and Behavioral Sciences: Elsevier

Jahangir, N., Akbar, M. M. \& Haq, M. (2004). Organizational Citizenship Behavior: It ${ }^{\text {ee }} \mathrm{s}$ Nature and Antecedents. BRAC University Journal, 1 (2).

Jamilah, S. (2016). Rancangan Internalisasi Budaya Perusahaan PT PLN (Persero) Wilayah Sumatera Utara. Laporan Praktik Kerja Profesi Psikologi. Medan: Universitas Sumatera Utara.

Karismawan. (2005). Iklim Kerja Perusahaan. Jakarta: Balai Pustaka.

Luthans, F. (2006). Organizational Behavior. New York: McGrawHill.

Organ, D.W., Podsakoff, P.M. \& MacKenzie, S.B. (2006).

*Korespondensi mengenai penelitian ini dapat dilayangkan kepada: Psikologia@usu.ac.id
Organizational Citizenship

Behavior: Its Nature, Antecedents, and Consequences, SAGE Publications.

Pasca, P.R. \& Banani, A. (2015). Pengaruh Keadilan Organisasi Organizational Silence Dan Kepuasan Kerja Terhadap Organizational Citizenship Behavior. Jurnal Ekonomi dan Bisnis. Unsoed, Purwokerto.

PIC Kinerja. (2015). Laporan Employee Engagement Survey (EES) PT PLN (Persero) Wilayah Sumatera Utara Tahun 2015. Medan - Indonesia.

PIC Kinerja. (2016). Laporan Employee Engagement Survey (EES) PT PLN (Persero) Wilayah Sumatera Utara Tahun 2016. Medan - Indonesia.

Priyatno, D. (2009). Mandiri Belajar SPSS (Statistical Product and Service Solution) untuk Analisis Data \& Uji Statistik. Yogyakarta: MediaKom.

Robbins, S.P. \& Judge, T.A. (2015). Perilaku Organisasi. Edisi Keenam belas. Jakarta: Salemba Empat.

Sahertian, P., and Soetjipto, B.E. (2011). Improving Employee ${ }^{e c} \mathrm{~s}$ Organizational Commitment, SelfEfficacy, and Organizational Citizenship Behavior Through the Implementation of Task-Oriented and Relationship-Oriented Leadership Behavior. The Business Review. Cambridge, 17 (2).

Saleh, L. (2015). Pengaruh Iklim Organisasi Dan Komitmen Organisasi Terhadap Pembentukan Organizational Citizenship Behavior (OCB) Karyawan Dalam

\section{Rekomendasi mensitasi:}

Jamilah,S. Mariatin,E. Novliadi,F. (2017). Pengaruh Keadilan Organisasi dan Keadilan Organisasi terhadap Organizational Citizenship Behavior. Psikologia :Jurnal Pemikiran dan Penelitian Psikologi, 12(3), 122- 
Rangka Peningkatan Kinerja. Jurnal Apresiasi Ekonomi, 3 (2).

Shweta, J. \& Srirang, J. (2010). Determinants of Organizational Citizenship Behavior: A Review of Literature. Journal of Management and Public Policy, 1 (2).

Soegandhi, V. M., Sutanto, E. M., \& Setiawan, R. (2013). Pengaruh Kepuasan Kerja dan Loyalitas Kerja Terhadap Organizational Citizenship Behavior. AGORA: Jurnal Manajemen Bisnis. UK Petra: Surabaya.

Steers, R.M., Porter, L.W. \& Bigley, G. A. (2003). Motivation and Work Behavior. New York: Mc GrawHill Book Company.

Sugiyono. (2012). Metode Penelitian Kuantitatif Kualitatif dan $R \& D$. Alfabet: Bandung.

Super, D. W. (1990). A life-space approach to career development. In D. Brown \& L. Brooks (Ed.), Career choice and development: Applying contemporary approaches to practice ( $2^{\text {nd }}$ ed., $p$. 197-261) San Fransisco, CA : Jossey Baass.

Suwandewi, T.N \& Sintaasih, K.D. (2016). Keadilan Organisasional dan Komitmen Organisasional: Efeknya Terhadap Organizational Citizenship Behavior. E-Jurnal Manajemen Unud, 5 (7).

Ukkas, I \& Latif, D. (2017). Pengaruh Iklim Organisasi dan Komitmen Organisasi Terhadap Organizational Citizenship Behavior (OCB). Jurnal Equilibrium, 6 (1).
Widyana, S. F. (2014). Pengaruh Iklim Organisasi dan Kepuasan Kerja Terhadap Perilaku Keanggotaan Organisasi dengan Variabel Kontrol Status Pegawai. (Tesis). Universitas Pendidikan Indonesia: Bandung.

Widyaningrum, W. E. (2009). Pengaruh Keadilan Organisasi Terhadap Kepuasan Kerja, Komitmen Organizational Citizenship Behavior Pegawai (Studi Kasus di Rumah Sakit Bersalin Pura Raharja Surabaya). Jurnal Ekonomi Tahun $X X$. Ubhara: Surabaya.

Wijayanto, V. R. (2007). Hubungan Antara Kepuasan Kerja dan Disiplin Kerja Karyawan. Jurnal Psikologi. Universitas Sanata Dharma.

Wirawan. (2007) Budaya dan Iklim Organisasi. Jakarta: Salemba Empat.

Wisnu, W. (2017). Pengaruh Iklim Organisasi Terhadap Organizational Citizenship Behavior Pegawai Perwakilan BPKP Provinsi Lampung dengan Kepuasan Kerja Sebagai Variabel Moderasi. (Tesis). Universitas Lampung: Bandar Lampung.

Zeinabadi, H. \& Salehi, K. (2011). Role of Procedural Justice, Trust, Job Satisfaction, and Organizational Commitment in Organizational Citizenship Behavior (ocb) of teachers: Proposing a modified social exchange model. Procedia Social and Behavioral Sciences: Elsevier 
*Korespondensi mengenai penelitian ini dapat dilayangkan kepada: Psikologia@usu.ac.id
Rekomendasi mensitasi:

Jamilah,S. Mariatin,E. Novliadi,F. (2017). Pengaruh

Keadilan Organisasi dan Keadilan Organisasi terhadap 